\title{
Det nya ägandet
}

\section{Av Barbro Bloom, magisterstudent i nordiska språk vid Växjö universitet}

De flesta människor äger någonting: ett hus, en cykel, möbler, böcker eller åtminstone kläderna på kroppen. Det är konkreta ting som man kan bevisa sin äganderätt till genom lagfartsbevis, registreringsbevis eller kvitto. På senare tid har verbet äga i vissa sammanhang börjat uppträda i kombination med nya ord. Birgitta Lindgren har i artikeln Några nyare ord $i$ svenskan i Svenska språknämndens tidskrift Språkvård nr 1/2004 uppmärksammat och tagit med äga frågan (el. problemet). Det är en ny form av ägande där det handlar om abstrakta objekt. Man talar om att äga frågan, att äga problemet, att äga processen och att äga utvecklingen.

Jag har studerat fraser med äga följt av de direkta objekten frågan, problemet, processen och utvecklingen i syfte att undersöka vad ägande betyder i dessa ordsammanställningar och om någon förändring $\mathrm{i}$ betydelse uppstår i jämförelse med andra, mer konventionella verb, t.ex. behandla frågan, lösa problemet, följa processen eller styra utvecklingen. Fraserna har studerats i strukturellt och funktionellt avseende. Den verkan de nya fraserna får i socialt avseende har jag också ägnat funderingar.[1]

\section{Äga i nya sammanhang}

Äga finns i flera nya sammanhang. Inom sport talas det om att äga bollen, vilket jag tolkar som ett nytt uttryck för att behärska spelet eller leda matchen. I ett lokalt annonsblad berättas om ett popband bestående av tre flickor som efter mycket tjat fått tillstånd att provsjunga en låt som ansågs för avancerad för dem och hur de när de gick in i studion ägde låten totalt. Något tidigare skulle de antagligen ha sagt att "den satt perfekt" eller "stämde precis".

I den amerikanska filmen Will Hunting som sändes i svensk tv den 12 februari 2003 säger huvudrollsinnehavaren på ett ställe: "The music owns you." I översättning blir meningen: "Musiken får makt över en." Här äger Will inte musiken; den äger honom. Det är sålunda ett abstrakt substantiv som är subjekt, och jag finner en parallell till i en av de texter som ingår i min undersökning, nämligen den i Göteborgs-Posten 23 februari 1999: "Vi försöker ta ett initiativ och äga problemet i stället för att problemet äger oss." (min kursivering).

Misstanken att äga-fraserna är översättningslån bekräftades vid sökning på Internet. I juni 2003 fick jag via sökmotorn Google följande träffar:

$\begin{array}{lr}\text { Fras } & \text { Antal } \\ \text { own the issue } & 880 \\ \text { own the problem } & 4580 \\ \text { own the procedure } & 191 \\ \text { own the development } & 734\end{array}$

De svenska motsvarigheterna består i mitt studiematerial av 41 tidningstexter hämtade från databaserna Mediearkivet och Presstext enligt följande:

$\begin{array}{lrl}\text { Fras } & \text { Antal } & \text { Första förekomst } \\ \text { äga frågan } & 37 & 1997 \mathrm{i} \mathrm{DN}\end{array}$


äga problemet

äga processen

äga utvecklingen
71998 i Expressen

52000 i Kvällsposten och Expressen

11996 i Aftonbladet

Nära nog hälften av fraserna i materialet är från 2002. Äga i förening med de här aktuella objekten kan ha förekommit i andra texter innan de kom i tidningstexter. Att exakt datera en språkutveckling är vanskligt. Sökning i Språkbankens konkordanser gav inga träffar.

De tidningsgenrer som fraserna förekommer i är: referat, nyheter, reportage, insändare, ledare, intervjuer, debatter, krönikor och reflektioner. Texternas teman är allmänpolitiska frågor, medicin och sport. Äga-uttrycken är påfallande vanliga i texter från den offentliga sektorn, men används också av journalister, politiker och tjänstemän på olika nivåer och av privatpersoner. Direkta citat är vanliga men också inbäddningar, det vill säga att någon annans röst också hörs men inte lika tydlig. I vissa fall baserar sig texterna på andra texter som är riktade till speciella mottagare som till exempel i en intervju i Kvällsposten och Expressen 30 april 2000. Där citeras KA2-chefen Günter Villman som har skrivit brev till sitt Högkvarter, Yrkesinspektionen och Arbetarskyddsstyrelsen och frånsagt sig ansvaret för KA2-personalens psykosociala arbetsmiljö: "Eftersom jag inte äger processen kan jag inte heller stå för den, därför borde ÖB ta hem ansvaret."

\section{Äga-frasernas struktur}

Så gott som alla meningar där äga ingår är jakande påståenden i presens. Den som äger är oftast inte sändaren av texten utan någon annan som omtalas, d.v.s. det är något man hävdar om andra. "Men det är Fritids- och turistnämnden som 'äger' frågan" (min kursivering), säger en intervjuad kaféägare i Nerikes Allehanda 10 september 2002. När den talande eller skrivande själv står för ägandet omnämns det så gott som alltid som ett kollektivt ägande. Ett undantag är politikern Stella Fares uttalande i DN 9 juni 2000: "Det viktigaste är att jag politiskt äger frågan lika mycket som han." Men hon fortsätter: "Och jag tänker se till att det blir som vi vill" (min kursivering). Meningen är inte helt typisk eftersom intervjupersonen här talar om ett framtida ägande. I materialet är nutidsperspektivet klart framträdande och mest frekvent. Äger frågan, problemet, processen eller utvecklingen är något man gör just nu; det är något pågående och högst aktuellt. Någon gång har ägandet pågått en tid: "Regeringen har nu ägt frågan sedan början av april" (Göteborgstidningen och Expressen 29 november 2001), där det framkommer en irritation över att beslut dröjer.

Att äga-fraser förekommer i negerade satser är ovanligt. "Kommunen äger inte frågan eftersom det är Vägverket som avgör om bron ska bli av" (Orusts kommunalråd Catharina Bråkenhielm (s) i Borås Tidning 27 juni 2002).

Ingenstans står det att någon "äger ett problem", "äger frågor" eller "äger processer" utan det är singularis och bestämd form som är helt förhärskande. Däri liknar fraserna lexikaliserade verbfraser där substantivet normalt inte kan ha alternativa former i species och numerus, t ex "föreställningen äger rum" eller "tolkningen äger företräde". Skillnaden är att i de lexikaliserade fraserna står substantivet i obestämd form. I ett annat fall av lexikaliserad fras kan substantivet bara stå med framförställd bestämning, genitivattribut: "Det äger sin riktighet." En sådan konstruktion med genitivattribut kan också de nya ägafraserna ha: "Det är förvaltningen som äger sin kvalitetsutveckling."

Den bestämda formen på objektet visar att frågan, problemet och processen förutsätts kända. Det är ett slags referensbindning där orden syftar på den företeelse som det berättats om i texten, och de utgör en modifierad upprepning. Utvecklingen däremot definieras som unik, "Historien har också visat att de dogmatiska, de som tror sig äga utvecklingen oftast får fel" (Aftonbladet 7 januari 1996).

\section{Attityder och processer}


Det finns knappast några garderingar i meningar där äga-fraserna förekommer, om man inte ska tolka vissa skribenters bruk av citationstecken runt ordet äga som en form av gardering. "Valforskare brukar tala om att partier 'äger' vissa frågor" (ledare i DN 25 juni 1997). Mest förekommer citationstecken i de tidigaste texterna, och det kan vara ett tecken på att skribenten vill markera att han eller hon är medveten om att konstruktionen inte är vedertaget. En annan tolkning är att skribenterna inte är helt övertygade om det är ägande det är fråga om.

Emfatiska ord förekommer knappast alls. Man förstärker inte sina uttalanden med ord som fullkomligt, det råder inget tvivel om eller liknande utan konstaterar kort och gott vem som äger och vem som inte gör det.

Att äga en fråga verkar innebära att besluta och ta ansvar, och det finns tillfällen då detta är komplicerat och besluten blir ifrågasatta. I sådana lägen blir gissningsvis ägande inte så attraktivt, utan man är belåten med att kunna hänvisa till den instans som handhar frågan. I andra fall innebär att äga frågan ökad frihet och självständighet, något som är uppskattat. "Nu kommer vi att äga processen själva, vi avgör kvalitetskriterierna" (prorektor Lena Nordblom vid Högskolan i Borås i Borås Tidning 6 juni 2002). I artikeln skymtar tillfredsställelse fram över att högskolan har fătt generell rätt att utbilda magistrar och att prorektorn tycker det är ett förtroende som Högskoleverket visat.

Meningar kan uttrycka ett faktum men också ett något mindre säkert eller ett blott troligt förhållande, en tänkbar möjlighet eller något rent hypotetiskt. Som jag skrivit ovan förekommer få tveksamheter. Alla påståenden i texterna i materialet är faktiska. Inga sannolikheter eller antaganden förekommer. "Det är FN som äger problemet" (GP 10 januari 2003). Meningar som "Det är troligen FN..." eller "Om FN skulle äga problemet..." förekommer inte i materialet.

Av de processer som kan förekomma i en proposition (handling, händelse, tillstånd eller inre, mental process) representerar äga-fraserna uteslutande ett tillstånd. Verbet äga är ett statiskt verb. Mentala processer kommer inte fram i de undersökta uttrycken, men ett par av texterna har exempel på sådana. I en krönika i Dagens Nyheter den 19 oktober 2002 skriver Ulf Berggren om rätten att tala fritt.

Yttrandefrihet kan ha olika innebörder. I liberala demokratier används begreppet ofta i överförd bemärkelse.

Människor som inte får komma till tals i offentligheten kritiserar gärna politiker, redaktörer och andra makthavare för att göra våld på det fria ordet.

Sällan handlar det om lagar och polisingripanden. Problemet är inte statliga repressalier utan att medborgare - rättmätigt eller felaktigt - känner sig utestängda från samhällsdebatten.

Under 80- och 90-talet har en växande flora av nya begrepp försökt definiera denna mer subtila form av maktutövning. Politisk korrekthet, problemformuleringsprivilegium, diskurs, dagordningssättande, "äga frågan" - problembarn har många namn.

"Medborgare känner sig utestängda" är exempel på en mental process som har sitt upphov bland annat i uttrycket äga frågan enligt författarens mening.

Äga-fraserna vore tänkbara med en meningskonstruktion där objekt och subjekt byter plats och med verbet äga utbytt mot tillhöra. "Nu kommer processen att tillhöra oss." Andra verb än äga är gångbara i sammanhangen. Om process kan sägas att den styrs, inväntas eller avvaktas. Problem är något som kan lösas, redas ut eller åtgärdas. Utvecklingen kan ledas, styras eller den rusar fram. Det är dynamiska verb som uttrycker att något händer, att en förändring sker. De ger en livfullare skildring än det statiska äga som för tankarna till juridiken. Att äga är bara ett konstaterande och emotionellt neutralt. 


\section{Användning och sammanhang}

Materialet består av tidningstexter, och de teman som behandlas har med samhällsfrågor att göra. Många av texterna bygger på andra texter från företrädesvis den offentliga sektorn. Genom användningen av de nya äga-fraserna förändras sättet att tala och skriva om verksamhetsområdena, och en form av intertextualitet uppstår genom att uttrycken sprids till flera områden, t ex det sociala, politiska och medicinska. Intressant att notera är att bland de diskurser jag urskilt finns inte den juridiska med där verbet äga främst hör hemma.

Att äga medför att ha makt. Att äga frågan innebär ofta myndighetsutövning. I fråga om problemet är kopplingen till makt inte lika entydig. Det beror på att problem som är synonymt med fråga också i allmänt språkbruk används i betydelsen svårigheter. Den som befinner sig i ett sådant predikament har inte direkt någon makt. Att äga processen markerar självständighet visavi uppdragsgivare i högre eller mindre grad.

En social funktion av äga-fraserna är att de är utestängande. Den som äger frågan bestämmer utgången i ett ärende eller sätter åtminstone dagordningen. En annan funktion av äga-fraserna är att de kan vara avståndstagande. Att säga till någon "det är du som äger problemet" kan vara en markering att man förväntar sig att personen ska hantera och lösa sina problem själv.

Hur blir någon ägare? I inget fall har ägandet av de aktuella objekten tillkommit genom köp. Någon merkantil verksamhet är det således inte fråga om. När myndigheter äger en fråga har de fått den genom bestämmelser i lagar och förordningar. Ett politiskt parti som äger frågan har varit snabbast med att föra ut frågan i debatten och genom sitt initiativ blivit ledande. En form av tillskansad makt utan rättslig grund visas i ett citat ur FaluKuriren 15 februari 2003: "Samtidigt vet alla aktörer att USA 'äger frågan' även om FN i nuläget har en period av initiativkraft."

\section{Framställningsformer}

Den kritiska diskursanalysen är intresserad av att klarlägga de ideologiska konsekvenser som olika framställningsformer kan ha (Winther Jörgensen \& Phillips 2000:87). Om man till exempel använder passiv form och utesluter agenten blir det svårt att hitta någon som kan lastas eller ställas till ansvar för det som hänt. I de fraser jag arbetat med är förhållandet närmast det omvända. Agenten nedtonas aldrig. Någon aktör äger alltid problemet. Om ägandet innebär fullständig kontroll är däremot inte lika säkert. En fråga som en myndighet ägt övergår ibland i verkställighet hos någon annan aktör.

De undersökta fraserna kan parafraseras på flera sätt, och den ersättning för äga som oftast fallit sig naturlig är att ha ansvar för, att besluta $i$ eller att hantera. De konventionella fraserna är ofta konstruerade med hjälpverbet $h a+$ substantiv. Meningarna kan också skrivas med kopulaverbet vara och ett adjektiv (ex. vara beslutande). Dessa fraser är längre än äga-fraserna. När konstruktionen av meningarna är densamma som av ägafraserna är skillnaden att verben i de konventionella fraserna ofta är dynamiska. Om man t.ex. skriver att någon gör frågan till sin används ett dynamiskt verb som uttrycker handling och anger en agent. En mening som: "Det är inte bara kurderna som äger problemet" kan omskrivas med ett annat verb och genom att objekt och subjekt byter plats: "Problemet angår inte bara kurderna". Om något angår en befinner man sig i ett tillstånd av engagemang.

De konventionella meningskonstruktionerna är ordrikare än konstruktionerna med äga. Någon avgörande betydelseförändring innehållsmässigt uppstår inte genom att använda verbet äga i stället för exempelvis ha ansvar för, hantera eller besluta om. En skillnad uppkommer ändå genom ordens valörer och konnotationer. Med äga uppstår associationer till ekonomisk och juridisk verksamhet, och verbet äga ger inte i sig upphov till någon 
mental process. Fraskonstruktionen framstår som saklig och klinisk, befriad från emotiva funktioner.

\section{Varför används äga-uttrycken?}

Anledningen till att äga-uttrycken börjat användas kan inte fastställas inom ramen för min undersökning. Man kan endast spekulera över om det är ett tidens tecken att man vill framstå som mäktig, potent, exakt och säker. Äga-fraserna medför ett distinkt, precist och språkligt ekonomiskt sätt att uttrycka sig. Det är ett fenomen som man känner igen från datorernas värld där frågor måste formuleras mycket exakt för att svar ska erhållas från programmen. Enligt sociologen Baudrillard (Moe 1995:258) är det "datorns binära idiotspråk som blivit vårt eget 'digitaliserade' och slagordspräglade språk".

Uttrycken med äga är klargörande för var makt och befogenheter ligger. Som vi sett ovan finns det de som också hävdar att uttrycken bidrar till utestängande och en subtil form av maktutövning.

Språklig jargong utvecklas där människor kommer samman förenade av liknande arbetsuppgifter eller samma intressen, och i strävan efter tillhörighet till en viss grupp tillägnar sig människor de ord och termer som är gångbara där.

Att fraserna uppfattas som utestängande kan leda till att människor inte engagerar sig vid de tillfällen som står till buds eller i de sammanhang där det vore möjligt. Därigenom kan äga-fraserna utgöra ett demokratiproblem.

\section{(C) Barbro Bloom}

\section{Litteratur}

Moe, Sverre 1995: Sociologisk teori, Studentlitteratur, Lund, ISBN 91-44-49431

Winther Jørgensen, Marianne \& Phillips, Louise 2000: Diskursanalys som teori och metod, Studentlitteratur, Lund, ISBN 91-4401016-8

www.presstext.prb.se

www.mediaarkivet.se

spraakbanken.gu.se/lb/konk/

[1] Undersökningen är gjord enligt en tredimensionell modell för diskurs som social praktik (Winther Jörgensen \& Phillips 2000:74). 